\title{
Natural hydroclimatic forcing of historical lake volume fluctuations at Devils Lake, North Dakota (USA)
}

\author{
Paul E. Todhunter \\ University of North Dakota, paul.todhunter@und.edu \\ Rhonda Fietzek-DeVries \\ University of North Dakota
}

How does access to this work benefit you? Let us know!

Follow this and additional works at: https://commons.und.edu/geo-fac

Part of the Geography Commons

\section{Recommended Citation}

Paul E. Todhunter and Rhonda Fietzek-DeVries. "Natural hydroclimatic forcing of historical lake volume fluctuations at Devils Lake, North Dakota (USA)" (2016). Geography \& Geographic Information Science Faculty Publications. 2.

https://commons.und.edu/geo-fac/2

This Article is brought to you for free and open access by the Department of Geography \& Geographic Information Science at UND Scholarly Commons. It has been accepted for inclusion in Geography \& Geographic Information Science Faculty Publications by an authorized administrator of UND Scholarly Commons. For more information, please contact und.commons@library.und.edu. 


\section{Natural hydroclimatic forcing of historical lake volume fluctuations at Devils Lake, North Dakota (USA)}

Paul E. Todhunter*, Rhonda Fietzek-DeVries

Department of Geography, University of North Dakota, 221 Centennial Drive Stop 9020, Grand

Forks, North Dakota, USA, 58202-9020

*Email: paul.todhunter@und.edu

Phone: (701) 777-4593

Fax: (701) 777-6195 


\begin{abstract}
Devils Lake, a terminal saline lake in eastern North Dakota, has experienced catastrophic flooding over the past two decades producing direct damages in excess of \$1 billion (\$USD). We use three long-term datasets to examine the temporal coherence between historical lake fluctuations and basic hydroclimatic drivers. Monthly precipitation and mean monthly air temperature data are used to characterize long-term precipitation delivery and evaporative demand. Monthly water balance data for a representative location is used to assess basin soil moisture conditions. A lake volume time series documents lake volume fluctuation in response to long-term precipitation and regional soil moisture conditions. Three variables are derived from the datasets, each characterizing a different aspect of the region's hydroclimatology. A rescaling technique is applied to each variable to examine the temporal coherence and relative patterns of the variables, and to identify distinct homogeneous hydroclimatic regimes during the historical period.
\end{abstract}

The three rescaled variables show strong temporal coherence, and confirm 1980 as an abrupt transition year between two distinct long-term hydroclimatic modes. Mode 1, a longer and drier phase, runs from 1907-1980, while mode 2, a shorter and wetter phase, extends from 1981 to the present. Multi-decadal and century-scale fluctuations between these two modes are the key drivers of long-term lake volume fluctuations, upon which interannual- and interdecadalscale climatic variability are superimposed. The similar rates of change among the rescaled variables provides evidence in support of the conclusion that long-term natural hydroclimatological variability is the primary driver of observed lake volume changes at Devils Lake during the $20^{\text {th }}$ Century, and provides a foundation upon which to evaluate the potential 
contributing effects of anthropogenic climate change, and human alterations of the land use hydrology.

Keywords Devils Lake; lake volume; lake flooding, hydroclimatic variability; terminal lake 


\section{Introduction}

Terminal lakes are unique and dynamic hydrological systems that can experience relatively rapid changes in water surface elevation, lake area, and lake volume due to fluctuating lake water sources and sinks (Street 1980; Mason et al. 1994; Williams 1996). Because their water budget integrates multiple hydrological forcings, the paleolimnological record of lakelevel variability has been proposed as a natural proxy indicator of historical climatic variation (Mason et al. 1994, Williams 1996). Terminal lakes are also sensitive to changes in basin hydrology, however, and their water budgets can be impacted by human alteration of basin land use/land cover, and human abstractions from or contributions to tributary discharge. They require careful water management plans, and the assumed absence of human alteration of the lake water budget must be demonstrated before they can be used to monitor climate change (Williams 1996, 1998).

Devils Lake is a terminal saline lake in the Devils Lake closed sub-basin in eastern North Dakota (Fig. 1). The lake has experienced catastrophic flooding over the past two decades (Larson 2012). From 30 September 1992 to 30 September 2013 the lake level $\left(\mathrm{L}_{\mathrm{L}}, \mathrm{m}\right)$ rose from 433.62 to $442.75 \mathrm{~m}(\Delta=9.13 \mathrm{~m})$, falling short of its ordinary high water mark of $444.40 \mathrm{~m}$. At this lake level it would spill through the Tolna Coulee into the Sheyenne River, and become part of the Red River of the North drainage basin. During the same period, lake area $\left(\mathrm{L}_{\mathrm{A}}, \mathrm{km}^{2}\right)$ expanded from 179.9 to $694.6 \mathrm{~km}^{2}(\Delta=286 \%)$, and lake volume $\left(\mathrm{Lv}_{\mathrm{v}}, \mathrm{km}^{3}\right)$ increased from 0.704 to $4.003 \mathrm{~km}^{3}$ ( $\Delta=469 \%$ ) (Fig. 2). Direct federal and state payments for flood damages have exceeded \$1 Billion (\$USD); most of these expenditure have been for levee construction and levee raises to protect the City of Devils Lake, road raises and route alterations, and bridge raises 
(Zheng et al. 2014). Also included are over 500 property relocations and losses due to the absence of lakeshore management below the ordinary high water mark.

In an effort to control the rise of Devils Lake the State of North Dakota completed the first of two outlets in the summer of 2005. The capacity of this outlet, which artificially discharged water from the west end of Devils Lake to the Sheyenne River, was later expanded, and a second outlet with a greater capacity was completed in the summer of 2012. Prior to water year 2012 both outlets discharged a maximum of only $0.069 \mathrm{~km}^{3}$ of water a year, which was an insignificant factor in the lake water balance.

Although regional aspects of the Devils Lake flood hazard have been investigated (Todhunter and Rundquist 2004, 2008), the hydroclimatological basis of the more recent flooding has received less intensive examination (Vecchia 2008; Hoerling et al. 2010; Todhunter and Knish 2014). Bluemle (1995) argues that natural hydroclimatological forcing of lake level variation at Devils Lake during the Holocene should be assumed until proven otherwise, but notes that, since the early 1980s, many local stakeholders have attributed the lake rise to local agricultural and wetland drainage. Hydrological studies in the Upper Mississippi River Valley have shown that extensive agricultural land use/land cover change can have significant impacts upon runoff volume (Zhang et al. 2006; Tomer and Schilling 2009; Schilling et al. 2010). Furthermore, Drummond et al. (2012) have shown that the Northern Glaciated Plains ecoregion, which includes the Devils Lake basin, has experienced moderate levels of land cover change over the period 1973-2000.

The purpose of this study is to examine multiple, long-term, hydroclimatological datasets to examine the link between natural hydroclimatological forcings and historical fluctuations in lake volume. The analysis will determine whether the multiple datasets exhibit patterns that are 
consistent in magnitude and temporal timing with one another, and will provide a foundation upon which future investigations of the effects of anthropogenic climate change, and atmospheric teleconnection patterns upon the historical lake volume changes may be evaluated.

\section{Background}

\subsection{Long-term hydroclimatic variation in the northern Great Plains}

Bluemle et al. (1999) reviewed the geological record of Devils Lake lake-level fluctuations during the late Holocene and concluded that the natural condition for the lake is to be either rising toward overflow to the neighboring Stump Lake or Sheyenne River, or falling toward desiccation as a dry lake bed. He concluded that the lake had dried up completely five or six times and overflowed past the ordinary high water mark at least twice in the last 4,000 years.

Multiple paleolimnological indicators have been used to investigate Holocene climate variability of northern Great Plains saline lakes (Haskell et al. 1996; Fritz et al. 2000; Laird et al. 2003; Shapley et al. 2005). These studies use multiproxy indicators capturing decadal-scale temporal resolution of local climate to reconstruct long-term salinity fluctuations from which they infer variations in moisture availability. A regionally coherent pattern exists of major changes in moisture regimes from wet to dry, or vice versa, that occurred after a period of relatively stable climatic conditions (Haskell et al. 1996). The late Holocene contains large oscillations between longer duration and more frequent periods of high salinity-drier conditions, and shorter duration and more variable periods of low salinity-wetter conditions. The transitions between high salinity/low salinity modes appear to be relatively rapid, suggesting large and abrupt transitions in the climatic drivers controlling moisture availability (Haskell et al. 1996; Laird et al. 2003). The salinity changes also suggest a fluctuation between periods of greater or 
lesser degrees of aridity, rather than between periods of wet and dry climatic conditions (Fritz et al. 2000). Combining systematic, historical, and paleolimnological records can provide a more complete evaluation of long-term hydrological variability, which can aid and improve water management (Benito et al. 2004).

Climatic variations occur at various temporal scales ranging from interannual, interdecadal, multi-decadal, to centennial and longer. The longer multi-decadal to century-scale variations appear to be driven by slower internal variations in the climatic system possessing small amplitude but long duration (Garbrecht and Rossel 2002). Research on multi-decadal hydroclimatic variability in the United States has focused on quasiperiodic variations in sea surface temperature in the tropical Pacific Ocean (ENSO), eastern Pacific Ocean (PDO), and North Atlantic Ocean (AMO) (McCabe et al. 2004; McCabe and Wolock 2014). No single climatic index has emerged as a dominant driver for the northern Great Plains, and two or more indices may be in phase or out of phase with one another, at times weakening or reinforcing each index (Woodhouse et al. 2009). Kluver and Leathers (2015) found no significant correlation between the frequency of significant snowfall events, an important determinant of snowfall amount and spring runoff into Devils Lake, and several teleconnection patterns in the Upper Midwest region.

\subsection{Basin and lake hydrology}

The study site has a cold-dry climate classification according to the Thornthwaite climate classification system, with a continental climate marked by strong seasonality of precipitation and temperature (Grundstein 2008). It experiences long, cold, dry winters and short, warm summers of variable wetness. The average annual precipitation is $450 \mathrm{~mm}$, and the average 
annual temperature is $3.8^{\circ} \mathrm{C}$. More details on the regional climate are given in Jensen (1972) and Rosenberry (2003).

Detailed hydrological investigations of the lake water balance and the hydroclimatology of the lake's contributing upper basin are reported in Wiche (1986, 1992), Ryan and Wiche (1988), and Vecchia (2008). Wiche and Pusc (1984) estimate that shallow ground water inflow from glacial till deposits surrounding the lake and deep ground water contributions to the lake are only $0.0037 \mathrm{~km}^{3} \mathrm{yr}^{-1}$, and thus are not a significant factor in explaining annual lake fluctuations. In the absence of significant ground water terms, the differential equation for the water balance of Devils Lake is:

$$
\frac{d L_{V}}{d t}=\mathrm{R}+\mathrm{PL}_{\mathrm{A}}-\mathrm{EL}_{\mathrm{A}}
$$

where $\mathrm{Lv}_{v}$ is the lake volume $\left(\mathrm{km}^{3}\right), \mathrm{t}$ is time, $\mathrm{R}$ is the surface runoff into the lake $\left(\mathrm{km}^{3}\right), \mathrm{P}$ is the direct precipitation onto the lake surface $(\mathrm{m}), \mathrm{L}_{\mathrm{A}}$ is the lake area $\left(\mathrm{km}^{2}\right)$, and $\mathrm{E}$ is the evaporation from the lake surface $(\mathrm{m})$. In most years, direct precipitation onto the lake surface is the major input to the lake water balance. In a small percentage of years surface runoff of spring snowmelt provides the majority of water input to the lake; this can result in sudden and dramatic rises in lake volume (Fig. 2). Direct evaporation from the lake, however, exceeds direct precipitation onto the lake by about $240 \mathrm{~mm}$ a year. Therefore, the lake volume time series is marked by sudden rises, followed by long protracted drawdowns (Vecchia 2008). Precipitation-runoff relationships in the upper basin are strongly non-linear, highly dynamic in time, and subject to thresholds and lags due to basin memory effects; these aspects of the basin and lake hydrology have not been thoroughly investigated to date (Shook and Pomeroy 2011).

\section{Data and methods}


3.1 Lake hypsometry and lake volume time series

Observations of $\mathrm{L}_{\mathrm{L}}$ for Devils Lake include sporadic field surveys prior to 1901, annual measurements from 1901-1930, monthly measurements from 1931-1965, and daily gauge readings from 1965 to the present (USGS 2013). The USGS installed a permanent gauge along Creel Bay in 1965 at $48^{\circ} 05^{\prime} 58^{\prime \prime} \mathrm{N}$ and $98^{\circ} 54^{\prime} 10^{\prime \prime} \mathrm{W}$. The complete lake hypsometry defining the relationships between lake level, lake area, and lake volume are normally not known for closed lakes, but are available for Devils Lake. Tables of $\mathrm{L}_{\mathrm{L}}-\mathrm{L}_{\mathrm{A}}$ and $\mathrm{L}_{\mathrm{L}}-\mathrm{L}_{\mathrm{V}}$ relationships for lake levels between 426.7-445.6 m (1400.0-1462.0 feet) were obtained from the USGS (2014) and used to create a $\mathrm{Lv}_{V}$ time series from the historical $\mathrm{L}_{\mathrm{L}}$ series. Lake levels on 30 June were used in order to create the longest and most serially uniform annual lake volume time series possible.

\subsection{Monthly precipitation and air temperature data}

Monthly precipitation and mean monthly maximum and minimum air temperature were obtained from the PRISM web page for the period 1895-2011 (www.prism.oregonstate.edu) by interpolating values from the PRISM database based upon the coordinates of the USGS gaging station on Devils Lake. PRISM data has been previously validated (Daly et al. 2008), and has been used extensively in hydroclimatological investigations (Sankarasubramanian and Vogel 2003; Small et al. 2006; Crimmins et al. 2011). Its use in providing a first-order assessment of the precipitation and temperature profile of the Devils Lake Basin is justified. First, the differential equation governing the lake water budget contains direct precipitation onto the lake surface (Mason et al. 1994). Areal precipitation within the closed lake basin is amplified into runoff (R) through soil moisture, which integrates basin precipitation and evapotranspiration and controls runoff in space and time. Second, the climatological gradients of mean precipitation and temperature vary gradually over short distances in the Great Plains Region of the United States 
(Rosenberg 1986), and there is very limited topographical relief within the basin (Wiche and Pusc 1984). Finally, even at its current historical maximum lake area is only about $8 \%$ of total basin area, so a single point representation of the open water lake environment is a sufficient first-order approximation.

\subsection{Water balance model}

The water balance is a fundamental concept in hydroclimatology. Water balance modeling provides a quantitative framework for understanding the physical relationship between climatic and hydrologic variables, and how the temporal variability of soil moisture storage controls the partitioning of precipitation into evapotranspiration and runoff (Hay and McCabe 2002). This study uses the monthly water balance model implementation of McCabe and Markstrom (2007) driven by the monthly temperature and precipitation data described in Section 3.2 .

The model includes six input parameters: runoff factor (fraction), direct runoff factor (fraction), soil moisture storage capacity $(\mathrm{mm})$, rain temperature threshold $\left({ }^{\circ} \mathrm{C}\right)$, snow temperature threshold $\left({ }^{\circ} \mathrm{C}\right)$, maximum snowmelt rate of snow storage (fraction). All six input parameters were set to their default values since sensitivity tests showed that model results varied little across a wide range of input parameter values (Hay and McCabe 2002). One of the study sites used for model development and sensitivity tests was the Sheyenne River near Cooperstown, immediately south of the Devils Lake Basin. That station also showed little sensitivity of model results to the range of input parameter values, so no new sensitivity analyses were conducted for the Devils Lake Basin.

The model first divides monthly precipitation into separate rain and snow components based upon the monthly precipitation, monthly mean air temperature, and the rain and snow 
temperature threshold input parameters. The snow component accumulates as snow storage, while a small portion of the rain component is abstracted as determined by the direct runoff factor input parameter. The non-abstracted rain component is added to monthly snow melt to compute the monthly total liquid water input to soil moisture storage. This monthly snow melt total is dependent upon the monthly snow storage, and a snow melt factor, which is based upon the monthly mean air temperature, the rain and snow threshold temperature input parameters, and the maximum snowmelt rate of snow storage input parameter.

The calculation of potential evapotranspiration is based upon the Hamon equation, which includes a saturated water vapor density term determined from mean monthly air temperature, and a daylight hour term based upon station latitude. Actual evapotranspiration is dependent upon the monthly total liquid water input to soil moisture storage, potential evapotranspiration, and soil moisture storage. The withdrawal of soil moisture to meet actual evapotranspiration proceeds as a linear function of the ratio of soil moisture storage to the soil moisture storage capacity. For the actual governing equations, and model calculations of variables not used in this analysis, the reader is referred to Hay and McCabe (2002), Wolock and McCabe (1999) and McCabe and Markstrom (2007).

Wolock and McCabe (1999) compared modeled versus measured monthly runoff for 344 climate divisions in the United States, while Hay and McCabe (2002) conducted similar validations for 44 individual stations. Wolock and McCabe (1999) found that the fundamental factors affecting the timing and magnitude of mean annual runoff - water supply, water demand, seasonality of water supply and water demand, and soil moisture storage - were successfully captured by the model. The adjusted R-square for mean annual runoff was 0.93 for the 344 climate divisions. The station analysis of Hay and McCabe (2002) showed similar results, with 
adjusted R-square values $\geq 0.50$ for monthly modeled versus measured runoff for 37 of the 44 stations. The poorest results were found for stations in the north central United States, and the glaciated plains. Hay and McCabe (2002) attribute this to the flat terrain, low runoff totals, and low ratio of runoff to precipitation for the region. Another significant explanatory factor concerns the unique hydrology of the glaciated northern prairies. Surface runoff in this region drains into innumerable local wetland depressions that were created during the last glaciation. Each depression must fill before it can begin to contribute runoff to lower sub-basins. A majority of many prairie regions consist of these non-contributing depressions that normally do not have a direct hydrological connection to a river network. As wetland water levels rise and fall the hydrological connection between adjacent wetlands are formed and broken. Thus, the drainage basin area contributing runoff to a stream gage varies dynamically with the water level and hydrological connectivity of the numerous wetland depressions. The contributing area to measured streamflow varies dynamically, is highly non-linear, and subject to thresholds of water storage and hydrological connectivity. Measured streamflow may show little increase although much local surface runoff is being produced, because local depressions are not yet filled or not hydrologically connected. Similarly, measured streamflow may show a sudden and significant increase with only a modest increase in local surface runoff (Shook and Pomeroy 2011; Ehsanzadeh et al. 2012; Shaw et al. 2012).

We assume that the McCabe and Markstrom model (2007) effectively models basin soil moisture conditions, and that the weak model validation results for measured streamflow are due to the unique nature of the 'fill-spill hydrology' for the northern prairie region (Shaw et al. 2012). Therefore, only the climatic and soil moisture-based model output variables are used in this analysis. Model-based moisture indices are useful indicators of regional moisture conditions, 
are directly related to important water resource variables such as runoff and groundwater recharge, and are effective in integrating the multiple dimensions of climate variability upon regional hydroclimatic variations (McCabe and Wolock 2002). These indices include calendar year estimates of annual potential evapotranspiration (PET, mm), annual precipitation minus mean annual potential evapotranspiration (PMPE, mm), annual actual evapotranspiration (AET, $\mathrm{mm}$ ), annual deficit (PET-AET, mm), ratio of annual AET to annual PET (AET/PET, fraction), mean monthly soil moisture storage (SM, mm), annual moisture index (IM100, $-100 \leq$ IM100 $\leq$ 100), and annual index of dryness (PET/P, fraction). All precipitation and water budget analyses run through water year 2011, the last year in which the combined artificial discharge from the two outlets was insignificant.

\subsection{Hurst rescaling of geophysical serial data}

Outcalt et al. (1997) present a method of Hurst rescaling that can be used to identify distinct physical regimes in geophysical time series. The method has been used to identify regime transitions and changes in the homogeneity of time series (Runnalls and Oke 2006; Todhunter 2012). The mean of the original geophysical time series is subtracted from each of the $n$ observations in the series. This series of deviations from the mean is accumulated to create a transformed time series $(R i)$.

The transformed time series can be plotted and visually inspected for regime transitions. An ascending (descending) trace indicates a period of above average (below average) time series values, where the steepness of the slope is related to the rate of deviations from the mean. Inflection points in the plotted time series indicate regime transitions from periods of positive to negative cumulative deviations from the mean (or vice versa).

The adjusted range of the transformed time series is calculated: 


$$
R_{n}=R_{\max }-R_{\min }
$$

The transformed time series is then normalized to create a normalized time series $\left(N R_{i}\right)$ ranging from 0 to 1.0 :

$$
N R_{i}=\left(R_{i}-R_{\min }\right) / R_{n}
$$

The graphical plots of the $R_{i}$ and $N R_{i}$ times series are much easier to interpret than the original time series, and present a more consistent means of decomposing a time series into more homogeneous subsets. Use of the $N R i$ time series is particularly advantageous for this study since it allows a direct comparison of separate geophysical time series having different metrics, starting and ending dates, and periods of record (Outcalt et al. 1997). Outcalt et al. (1997) estimate the Hurst exponent $(\mathrm{H})$ as follows:

$$
H=\log [R n / S n] / \log n
$$

where $\mathrm{Rn}$ is defined in equation [2], $\mathrm{Sn}$ is the standard deviation of the time series, and $\mathrm{n}$ is the number of observations in the time series. The Hurst exponent is a measure of persistence or long-term temporal correlation in a geophysical time series, with values often ranging from 0.5 to 1.0. A value of $\mathrm{H}$ near 0.5 indicates chaotic effects and an absence of long-term temporal correlation, while a value of $\mathrm{H}$ near 1.0 indicates extreme persistence (Outcalt et al. 1997).

\section{Results}

4.1 Lake volume time series

The composite $\mathrm{Lv}_{v}\left(\mathrm{~km}^{3}\right)$ time series is shown in Figure 2. At the time of first European contact the lake was decreasing in size, and reached a minimum Lv volume (area) of $0.045 \mathrm{~km}^{3}$ $\left(34.7 \mathrm{~km}^{2}\right)$ on 30 October 1940 . The lake experienced a general but sporadic lake expansion 
through 30 September 1992 when lake volume (area) reached $0.704 \mathrm{~km}^{3}\left(179.9 \mathrm{~km}^{2}\right)$. Over the past two decades Devils Lake has been characterized by explosive growth, attaining a Lv (area) of $4.003 \mathrm{~km}^{3}\left(694.6 \mathrm{~km}^{2}\right)$ on 31 January 2014. In mid-1999, when Devils Lake had a Lv of about $2.921 \mathrm{~km}^{3}$, it became hydrologically connected to Stump Lake, a separate saline lake to the east. Although the two lake systems formed a single lake after that time, this analysis will only consider the Devils Lake portion of the combined lake system after 1999. Lake volume at Devils Lake never reaches a steady-state condition, but is continuously adjusting to fluctuations in lake inputs, a hydrological feature exhibited by many closed lake systems (Mohammed and Tarboton 2011; Mason et al. 1994).

A histogram of monthly lake volumes is presented in Figure 3 for the period 30 January 1931 through 31 January $2014(\mathrm{~N}=974)$. Figure 3 shows the number of occurrences of $\mathrm{LV}_{\mathrm{V}}$ within predefined bins of fixed interval width; the histogram shows a distribution of lake volumes that is consistent with the multimodality of hydroclimatic regimes present in the paleohydrological record (Mohammed and Tarboton 2011).

\subsection{Annual precipitation and mean annual air temperature}

Time series for the annual precipitation and mean annual air temperature are shown in Figure 4 for the period 1896-2011 $(\mathrm{N}=116)$. Both variables are evaluated over a water year running from 1 October - 30 September. The high degree of interannual variability in the precipitation and air temperature regimes that characterizes the Great Plains is evident in the scatter of points (Rosenberg 1986). A nine-term binomial filter was fitted to each series to reduce the high frequency noise associated with interannual variability, and to better identify runs of wetter and drier spells. Linear regression analysis results indicate statistically significant 
trends toward increasing annual precipitation $(b=59.8 \mathrm{~mm}$ per century, $\mathrm{p}<0.05)$ and warmer mean annual air temperatures $\left(b=1.36^{\circ} \mathrm{C}\right.$ per century, $\left.\mathrm{p}<0.01\right)$.

\subsection{Water balance data}

We present results from three water balance variables. The first variable, PMPE, is a measure of water surplus, and is equal to annual precipitation $(\mathrm{P})$ minus annual potential evapotranspiration (PET). Wolock and McCabe (1999) found that mean annual PMPE explained 91 percent of the spatial variation in mean annual streamflow for the 344 climate divisions in the conterminous United States, and is an effective single measure of how regional water surplus determines regional surface runoff. The PMPE water year time series for the period 1895-2011 is shown in Figure 5a. Positive totals indicate humid years ( $P>P E T)$, while negative totals occur during sub-humid years $(\mathrm{P}<\mathrm{PET})$. Figure 5a reveals a high degree of interannual variability; PMPE is negative most years, although numerous positive PMPE years do occur. Interdecadal time scale variation of PMPE, shown by the thick black curve in Figure 5a, is nearly always negative, although dry spells of greater or lesser intensity do occur. The overall trend is positive, but not statistically significant because a downward trend in the first half of the series is followed by an upward trend in the latter half.

The second variable, PET-AET, is a measure of the annual water deficit, and is equal to the annual PET minus the annual actual evapotranspiration (AET). It is an indicator of the climatic demand for water relative to the climatic supply. The annual deficit (PET-AET) is shown in Figure 5b, and has a lower bound of zero. Positive deficit values indicate years when precipitation and stored soil moisture are unable to meet the atmospheric demand for water, with larger positive values of PET-AET corresponding to years with increasing soil dryness. PETAET also provides a comparison of the magnitude of water supply relative to water demand, but, 
unlike PMPE, directly incorporates soil moisture availability. Interannual- and interdecadalscale variability is evident (Fig. 5b); a long-term downward trend is found, but is not statistically significant, as an earlier trend toward increasing soil dryness is followed by a later trend toward decreasing soil dryness.

The third variable, SM, is the mean annual soil moisture content (mm). Soil moisture is a fundamental hydrological variable that regulates the conversion of moisture delivery (rain, snowmelt) into hydrological output (streamflow, lake levels). Greater persistence of mean annual soil moisture content is observed since low or high soil moisture content in year $i-1$ will be carried over into and correlated with low or high soil moisture content in year $i$. A prolonged period of lower mean soil moisture content separates periods of higher mean soil moisture content in the earlier and later portion of the time series.

\subsection{Normalized transformed geophysical serial data}

Normalized transformed time series plots of water year precipitation $\left(\mathrm{P}_{\mathrm{WY}}\right)$, calendar year mean monthly soil moisture storage $(\mathrm{SM})$, and 30 June lake volume $\left(\mathrm{Lv}_{\mathrm{V}}\right)$, are shown in Figure 6. These variables were chosen because they correspond most directly to the three basic categories of moisture status - meteorological, agricultural, and hydrological (Wilhite and Glantz 1985), and because soil moisture regulates the translation of moisture input into hydrological output. The plots reveal the presence of inflection points within each time series, and provide a comparison of the trend and timing of the cumulative deviations of each time series from its respective mean value.

The normalized Lv plot shows a continuous accumulation of negative deviations below the long-term mean from 1901 until reaching a minimum in 1980. Although lake level reached a 
minimum near 1940 (Fig. 2), the cumulative deviations of lake level below the long-term mean continued to be negative through 1980. In 1993, the normalized Lv series began an abrupt and rapid positive accumulation of deviations from the long-term mean value, reaching a maximum value in 2013. There is about a 15-year lag between the downward and upward Lv deviation pattern, and is due to the substantial hydrological inertia present in closed lake systems (Street 1980; Mason et al. 1994). The normalized plots of water year precipitation $\left(\mathrm{P}_{\mathrm{WY}}\right)$ and mean monthly soil moisture storage (SM) show similar patterns. The $\mathrm{P}_{\mathrm{WY}}$ plot has an inflection between positive and negative deviations from the long-term mean in 1906, followed by a general accumulation of negative deviations lasting until 1980. P $\mathrm{WY}_{\mathrm{Y}}$ values then begin a rapid accumulation of positive deviations to the end of the time series. The plot of the normalized SM series is very similar to the $\mathrm{P}_{\mathrm{WY}}$ series, only with a lagged inflection point occurring in 1916. The normalized $\mathrm{P}_{\mathrm{WY}}$ and SM plots exhibit interdecadal-scale variability during the downward trends ending in 1980, as well as during the upward trends continuing to the end of each series.

Other water balance variables show similar patterns to the SM trace in Figure 6. Water surplus (PMPE) and water deficit (PET-AET) are mirror opposites of one another (Fig. 7), and share inflection points in 1916 and 1980.

\section{Discussion}

Climatic variations across interannual and interdecadal time scales have received significant attention, yet it is the multi-decadal to century time scale variation that has the greatest impact upon water resources management and societal impacts (Stockton 1990). In his stochastic simulation of future lake levels at Devils Lake, Vecchia (2008) assumed that the longterm time series was consistent with a two-state climate model marked by abrupt transitions between two multi-decadal climatic modes. The year 1979 was identified as one such dry to wet 
phase transition (Vecchia 2008). Our analysis provides an objective means of examining multidecadal and century-scale climate change within a historical record, and identifies a hydroclimatic regime change that is consistent with the multi-modality of climatic modes so prominent within the Devils Lake paleolimnological record.

Our use of cumulative deviations from the long-term mean to identify transition years between distinct hydroclimatic regimes produces results consistent with the pattern of abrupt regime changes found in the paleolimnological record, and is in agreement with the analysis of Vecchia (2008), although it identifies 1980 as the transition year (Fig. 6). Our work provides a more objective basis for determining the regime change point, uses a much longer period-ofrecord, employs a more diverse set of hydroclimatic variables, and provides a more complete characterization of the mean hydroclimatic conditions for the two climatic modes (Table 1). Mode 1, the longer and drier phase, runs from 1907-1980, while the shorter and wetter phase, mode 2, extends from 1981-2011.

We also provide a rational characterization of the two climatic modes that, when sustained over long periods of time, produce profound changes in lake hydrology. Mode 2 water year mean annual precipitation ( $\mathrm{P}_{\mathrm{WY}}$ ) is $84 \mathrm{~mm}$ (20\%) greater than for mode 1, with $63 \mathrm{~mm}$ of this increase occurring during the five-month warm season of May-September ( $\mathrm{P}_{\mathrm{ws}}$, Table 1). This result is anticipated for a station with a continental precipitation regime (Jensen 1972). Although mean annual air temperature is $0.76^{\circ} \mathrm{C}$ warmer for mode 2 than for mode 1 , most of the warming occurs during the cold season $\left(1.32^{\circ} \mathrm{C}\right)$ when monthly PET values are generally below $10 \mathrm{~mm}$. Mode 2 mean annual potential evapotranspiration is only marginally higher $(15.8 \mathrm{~mm})$ because the warm season warming $\left(0.46^{\circ} \mathrm{C}\right)$ is less significant, and the PET computational procedure is insensitive to that small of a change in mean monthly air temperature. The large 
increase in $\mathrm{P}_{\mathrm{WY}}$ relative to PET for mode 2 versus mode 1, however, results in a 54\% reduction in the mode 2 mean PMPE value. The wetter mode 2 hydroclimatic regime experiences increased mean annual evapotranspiration (AET: $70 \mathrm{~mm},+17 \%$ ), reduced mean annual deficit (PET-AET: -54 mm, -38\%), and increased mean monthly soil moisture (SM: $38 \mathrm{~mm},+62 \%$ ). The three mean annual moisture indices - AET/PET, IM100, and PET/P - also show mode 2 to be a significantly less dry hydroclimatic mode.

Although most (but not all) of the years during mode 2 still classify as sub-humid years on an annual basis, modest increases in winter snowfall and spring temperatures sustained over the long term can lead to dramatic changes in the basin hydrological conditions during the spring (Table 1). Increased winter snowfall, more rapid spring snowmelt, frozen soils inhibiting significant infiltration, increased wetland water storage totals, and greater connectivity of wetland depressions can produce dynamic and non-linear increases in streamflow totals (Shaw et al. 2012; Ehsanzadeh et al. 2012; Kluver and Leathers 2015).

Interannual and interdecadal variability in the climatic supply and demand for water at the surface environment produces fluctuating patterns of meteorological, soil moisture, and hydrological states that are commonly out of phase with one another, exhibit significant lags, and can even be of different signs (Wilhite and Glantz 1985). During periods of multi-decadal to century-scale dry or wet phases, however, a more consistent relationship may develop between meteorological, soil moisture, and hydrological variables such as illustrated in Figures 6 and 7.

The normalized transformed water year precipitation amount $\left(\mathrm{P}_{\mathrm{WY}}\right)$ trace has inflection points in 1906 and 1980, and is the primary long-term driver of hydroclimatic change for this climatic region. The mean monthly soil moisture trace (SM) lags the $\mathrm{P}_{\mathrm{WY}}$ trace by about five years 
during the declining phase and for most of the rising phase of the $\mathrm{P}_{\mathrm{WY}}$ trace. The $\mathrm{L}_{\mathrm{V}}$ trace is generally in-phase with the $\mathrm{P}_{\mathrm{WY}}$ and SM traces during the falling phase, and experiences a flat bottoming out from about 1980 to 1993 . It then lags the other two traces by about 15 years, before becoming in-phase with them about 2005. Estimates of the Hurst exponent $(\mathrm{H})$ show that the $\mathrm{P}_{\mathrm{WY}}$ time series exhibits mild persistence $(\mathrm{H}=0.66)$, while a higher level of persistence is found for mean monthly soil moisture content $(\mathrm{H}=0.72)$, and even stronger persistence for lake volume $(\mathrm{H}=0.78)$. The strong persistence found in closed lake systems helps explain the slow and delayed response of lake volume to changes in the equilibrium climate as seen in Figure 6 (Mason et al. 1994). The long-term timing between the phases of the $\mathrm{P}_{\mathrm{WY}}, \mathrm{SM}$ and $\mathrm{Lv}_{\mathrm{v}}$ traces during the falling and rising limbs is generally consistent with a pattern of precipitation serving as the primary driver of hydroclimatic change, with soil moisture and lake volume lagging in time (Wilhite and Glantz 1985). Small departures between the trace phases is not unexpected, however, as strong hysteresis effects have been found between precipitation input and streamflow runoff during wetting and drying periods in northern prairie environments (Shook and Pomeroy 2011).

Regional soil moisture serves as a regulator between precipitation inputs and runoff response. Small but sustained precipitation increases (decreases) sustained over multi-decadal to century time scales appear to be amplified into much larger than normal moisture surpluses (deficits) and greatly increased (decreased) runoff (Garbrecht et al. 2004; Ryberg et al. 2014). These amplifications may be sufficient to explain the historical lake fluctuations at Devils Lake, independent of any basin land use/land cover changes that may have occurred. Natural climatic variability in the northern Great Plains may be so large as to make detection of climate signal resulting from anthropogenic climate change difficult. Alternatively, should anthropogenic 
climate change impact the nature or duration of the two climatic modes in this region, the effect upon future lake volumes might be profound.

\section{Conclusions}

Three long-term hydroclimatological datasets were examined to investigate the relationship between precipitation, soil moisture, and lake volume variations at Devils Lake over the historical record. The three datasets show physically-consistent and coherent temporal patterns over the historical record, and provide more complete documentation of how natural hydroclimatological variability has been a primary driver of the dramatic changes in $\mathrm{L}_{\mathrm{L}}, \mathrm{L}_{\mathrm{A}}$, and $\mathrm{Lv}$ observed during the $20^{\text {th }}$ Century at Devils Lake. Interannual- and interdecadal-scale climatic variability are superimposed upon two longer-term climatic modes, a longer and drier mode and a shorter duration and wetter mode, that are the key drivers of long-term lake volume fluctuations. Future work is needed to investigate the positive feedback processes by which long-term regional precipitation fluctuations are amplified into lake volume fluctuations, to determine the contribution of basin land use changes to increased surface runoff to the lake (Tomer and Schilling 2009), and to explore the link between teleconnection patterns and hydroclimatic variations in the northern Great Plains (Kluver and Leathers 2015).

Acknowledgements We thank Rick Thalacker for his work in making Figure 1. The careful reading and constructive comments from three anonymous reviewers is gratefully acknowledged. 


\section{References}

Benito G, Lang M, Barriendos M, Llasat MC, Francés F, Ouarda T, Thorndycraft VR, Enzel Y, Bardossy A, Coeur C, Bobée B (2004) Use of systematic, palaeoflood and historical data for the improvement of flood risk estimation. Review of scientific methods. Nat Hazards $31: 623-643$

Bluemle JP (1995) The fluctuating level of Devils Lake. North Dakota Geological Survey Newsletter 22:7-9

Bluemle JP, Sabel JM, Karlén W (1999) Rate and magnitude of past global climate changes. Environ Geosci 6:63-75

Crimmins SM, Dobrowski SZ, Greenberg JA, Abatzoglou JT, Mynsberge AR (2011) Changes in climatic water balance drive downhill shifts in plant species' optimum elevations. Science $331: 324-327$

Daly C, Halbleib M, Smith JI, Gibson WP, Doggett MK, Taylor GH, Curtis J, Pasteris PP (2008) Physiographically sensitive mapping of climatological temperature and precipitation across the conterminous United States. Int J Climatol 28:2031-2064

Drummond MA, Auch RF, Karstensen KA, Sayler KL, Taylor JL, Loveland TR (2012) Land change variability and human-environment dynamics in the United States Great Plains. Land Use Policy 29:710-723

Ehsanzadeh E, van der Kamp G, Spence C (2012) The impact of climatic variability and change in the hydroclimatology of Lake Winnipeg watershed. Hydrol Proc 26: 2802-2813

Fritz SC, Ito E, Yu Z, Laird KR, Engstrom DR (2000) Hydrologic variation in the northern Great Plains during the last two millennia. Quat Res 53:175-184

Garbrecht JD, Rossel FE (2002) Decade-scale precipitation increase in Great Plains at end of $20^{\text {th }}$ 
Century. J Hydrolog Eng 7:64-75

Garbrecht J, Van Liew M, Brown GO (2004) Trends in precipitation, streamflow, and evapotranspiration in the Great Plains of the United States. J Hydrolog Eng 9:360-367

Grundstein A (2008) Assessing climate change in the contiguous United States using a modified Thornthwaite climate classification scheme. Prof Geogr 60:398-412

Haskell BJ, Engstrom DR, Fritz SC (1996) Late Quaternary paleohydrology in the North American Great Plains inferred from the geochemistry of endogenic carbonate and fossil ostracodes from Devils Lake, North Dakota, USA. Palaeogeogr, Palaeoclimatol, Palaeoecol $124: 179-193$

Hay LE, McCabe GJ (2002) Spatial variability in water-balance model performance in the conterminous United States. J Am Water Resour Assoc 38:847-860

Hoerling M, Eischeid J, Easterling D, Peterson T, Webb R (2010) Understanding and Explaining Hydro-Climate Variations at Devils Lake. Unpublished NOAA Climate Assessment prepared for the Interagency Initiative to Address Flooding Issues at Devils Lake, ND

Jensen, RE (1972) Climate of North Dakota. North Dakota State Water Commission, Bismarck

Kluver D, Leathers D (2015) Regionalization of snowfall frequency and trends over the contiguous United States. Int J Climatol 35, DOI: 10.1002/joc.4292

Laird KR, Cumming BF, Wunsam S, Rusak JA, Oglesby RJ, Fritz SC, Leavitt PR (2003) Lake sediments record large-scale shifts in moisture regimes across the northern prairies of North America during the past two millennia. Proc Natl Acad Sci 100:2483-2488

Larson D (2012) Runaway Devils Lake. Am Sci 100:46-53

Mason IM, Guzkowska MAJ, Rapley CG, Street-Perrott FA (1994) The response of lake levels and areas to climatic change. Clim Change 27:161-197 
McCabe GJ, Markstrom SL (2007) A monthly water-balance model driven by a graphical user interface. U.S. Geological Survey Open-File Report 2007-1088, Denver: United States Geological Survey

McCabe Jr. GJ, Wolock DM (2002) Trends and temperature sensitivity of moisture conditions in the conterminous United States. Clim Res 20:19-29

McCabe Jr. GJ, Palecki MA, Betancourt JL (2004) Pacific and Atlantic Ocean influences on multidecadal drought frequency in the United States. Proc Natl Acad Sci 101:4136-4141

McCabe Jr. GJ, Wolock DM (2014) Spatial and temporal patterns in conterminous United States streamflow characteristics. Geophys Res Lett 41, doi:10.1002/2014GL061980

Mohammed IN, Tarboton DG (2011) On the interaction between bathymetry and climate in the system dynamics and preferred levels of the Great Salt Lake. Water Resour Res 47, doi:10.1029/2010WR009561

Outcalt SI, Hinkel KM, Meyer E, Brazel AJ (1997) Application of Hurst Rescaling to geophysical serial data. Geogr Anal 29:72-87

Rosenberg NJ (1986) Climate of the Great Plains Region of the United States. Great Plains Quart $7: 22-32$

Rosenberry, DO (2003) Climate of the Cottonwood Lake area. In: Winter TC (ed) Hydrological, chemical, and biological characteristics of a prairie pothole wetland complex under highly variable climate conditions: the Cottonwood Lake area, east-central North Dakota, U.S. Geological Survey Professional Paper 1675, USGS, Denver, pp 25-34

Runnalls KE, Oke TR (2006) A technique to detect microclimatic inhomogeneities in historical records of screen-level air temperature. J Clim 19:959-978 
Ryan GL, Wiche GJ (1988) Hydrology of the Chain of Lakes Tributary to Devils Lake and Water-Level Simulations of Devils Lake, Northeastern North Dakota. U.S. Geological Survey Water-Resources Investigations Report 88-4020, Bismarck, North Dakota: United States Geological Survey

Ryberg KR, Lin W, Vecchia AV (2014) Impact of climate variability on runoff in the NorthCentral United States. J Hydrolog Eng 19:148-158

Sankarasubramanian A, Vogel RM (2003) Hydroclimatology of the continental United States. Geophys Res Lett 30, 1363, doi:10.1029/2002GL015937

Schilling KE, Chan K-S, Liu H, Zhang Y-K (2010) Quantifying the effect of land use land cover change on increasing discharge in the Upper Mississippi River. J Hydrol 387:343-345

Sethre PR, Rundquist BC, Todhunter PE (2005) Remote detection of prairie pothole ponds in the Devils Lake Basin of North Dakota. GISc Rem Sens 42: 277-296

Shapley MD, Johnson WC, Engstrom DR, Osterkamp WR (2005) Late-Holocene flooding and drought in the Northern Great Plains, USA, reconstructed from tree rings, lake sediments and ancient shorelines. The Holocene 15:29-41

Shaw DA, van der Kamp G, Conly FM, Pietroniro A, Mertz L (2012) The fill-spill hydrology of prairie wetland complexes during drought and deluge. Hydrol Proc 26: 3147-3156

Shook KR, Pomeroy JW (2011) Memory effects of depressional storage in Northern Prairie hydrology. Hydrol Proc 25: 3890-3898

Small D, Islam S, Vogel RM (2006) Trends in precipitation and streamflow in the eastern U.S.:

Paradox or perception? Geophys Res Lett 33, L03403, doi:10.1029/2005GL024995

Stockton CW (1990) Climatic variability on the scale of decades to centuries. Clim Change $16: 172-183$ 
Street FA (1980) The relative importance of climate and local hydrogeological factors in influencing lake-level fluctuations. Palaeoecol Africa 12:137-158

Todhunter PE (2012) Uncertainty of the assumptions required for estimating the regulatory flood: Red River of the North. J Hydrolog Eng 17: 1011-1020

Todhunter PE, Rundquist BC (2004) Terminal lake flooding and wetland expansion in Nelson County, North Dakota. Phys Geog 25:68-85

Todhunter PE, Rundquist BC (2008) Pervasive wetland flooding in the glacial drift prairie of North Dakota (USA). Nat Hazards 46:73-88

Todhunter PE, Knish EA (2014) Lake flooding and synoptic weather-type frequency at Devils Lake, North Dakota between 1965 and 2010. Clim Res 61:191-201

Tomer MD, Schilling KE (2009) A simple approach to distinguish land-use and climate-change effects on watershed hydrology. J Hydrol 376: 24-33

United States Geological Survey (2013) USGS 05056500 Devils Lake nr Devils Lake, ND. http://nwis.waterdata.usgs.gov/nd/nwis/nwisman? (accessed 15 November 2013)

United States Geological Survey (2014) Devils Lake and Stump Lake Area-Capacity Table. http://nd.water.usgs.gov/devilslake/pdf/elevation-area-volume.pdf (accessed 18 February 2014)

Vecchia AV (2008) Climate simulation and flood risk analysis for 2008-40 for Devils Lake, North Dakota. U.S. Geological Survey Scientific Investigations Report 2008-5011, Denver: United States Geological Survey

Wiche G (1986) Hydrologic and climatologic factors affecting water levels of Devils Lake, North Dakota. Water-Resources Investigations Report 86-4320, Bismarck, North Dakota: United States Geological Survey 
Wiche GJ (1992) Hydrology and water-level fluctuations of Devils Lake, North Dakota. U.S. Geological Survey Water-Supply Paper 2340, Denver: United States Geological Survey Wiche GJ, Pusc SW (1994) Hydrology of Devils Lake Area, North Dakota. North Dakota State Water Commission Water Resources Investigation 22, Bismarck, North Dakota: North Dakota State Water Commission

Wilhite DA, Glantz MH (1985) Understanding the drought phenomenon: The role of definitions. Water Int 10:111-120

Williams WD (1996) What future for saline lakes? Environment 38:13-20, 38-39

Williams WD (1998) Management of Inland Saline Waters. Guidelines of Lake Management Vol. 6, International Lake Environment Committee, United Nations Environment

Programme

Wolock DM, McCabe GJ (1999) Explaining spatial variability in mean annual runoff in the conterminous United States. Clim Res 11:149-159

Woodhouse CA, Russell JL, Cook ER (2009) Two modes of North American drought from instrumental and paleoclimatic data. J Clim 22:4336-4347

Zhang Y-K, Schilling KE (2006) Increasing streamflow and baseflow in Mississippi River since the 1940s: Effect of land use change. J Hydrol 324:412-42

Zheng H, Barta D, Zhang X (2014) Lessons learned from adaptation response to Devils Lake flooding in North Dakota, USA. Reg Environ Chang 14: 185-194 


\section{TABLES}

Table 1 Comparison of mean hydroclimatic conditions for mode 1 (1907-1980) and mode 2 (1981-2011). Variables are: annual water year precipitation ( $\mathrm{PWY}_{\mathrm{WY}}$, annual cold season precipitation $\left(\mathrm{P}_{\mathrm{CS}}\right)$, annual warm season precipitation $\left(\mathrm{P}_{\mathrm{WS}}\right)$, mean annual water year air temperature $\left(\mathrm{T}_{\mathrm{WY}}\right)$, mean annual cold season air temperature $\left(\mathrm{T}_{\mathrm{CS}}\right)$, mean annual warm season air temperature ( $\mathrm{T}_{\mathrm{WS}}$ ), annual potential evapotranspiration (PET), annual precipitation minus annual potential evapotranspiration (PMPE), annual actual evapotranspiration (AET), annual potential evapotranspiration minus annual actual evapotranspiration (PET-AET), mean annual soil moisture (SM), ratio of annual actual evapotranspiration to annual potential evapotranspiration (AET/PET), annual moisture index (IM100), and the index of dryness (PET/P). The five-month cold season is from November through March; the five-month warm season is from May through September. PET, PMPE, AET, PET-AET, SM, AET/PET, IM100 and PET/P are calendar year totals; $\mathrm{P}_{\mathrm{WY}}, \mathrm{P}_{\mathrm{CS}}, \mathrm{P}_{\mathrm{WS}}, \mathrm{T}_{\mathrm{WY}}, \mathrm{T}_{\mathrm{CS}}$, and $\mathrm{T}_{\mathrm{Ws}}$ are water year totals.

\begin{tabular}{|c|c|c|c|c|c|c|c|}
\hline Variable & $\begin{array}{l}\mathrm{P}_{\mathrm{WY}} \\
(\mathrm{mm})\end{array}$ & $\begin{array}{c}\mathrm{P}_{\mathrm{CS}} \\
(\mathrm{mm})\end{array}$ & $\begin{array}{l}P_{W S} \\
(\mathrm{~mm})\end{array}$ & $\begin{array}{l}\mathrm{T}_{\mathrm{WY}} \\
\left({ }^{\circ} \mathrm{C}\right)\end{array}$ & $\begin{array}{l}\mathrm{T}_{\mathrm{CS}} \\
\left({ }^{\circ} \mathrm{C}\right)\end{array}$ & $\begin{array}{l}\text { TwS } \\
\left({ }^{\circ} \mathrm{C}\right)\end{array}$ & $\begin{array}{l}\text { PET } \\
(\mathrm{mm})\end{array}$ \\
\hline $1907-1980$ & 421.6 & 80.1 & 290.6 & 3.62 & -9.92 & 16.35 & 545.5 \\
\hline 1981-2011 & 506.0 & 86.8 & 353.7 & 4.38 & -8.60 & 16.81 & 561.3 \\
\hline Variable & $\begin{array}{l}\text { PMPE } \\
(\mathrm{mm})\end{array}$ & $\begin{array}{l}\text { AET } \\
(\mathrm{mm})\end{array}$ & $\begin{array}{l}\text { PET- } \\
\text { AET } \\
(\mathrm{mm})\end{array}$ & $\begin{array}{c}\mathrm{SM} \\
(\mathrm{mm})\end{array}$ & $\begin{array}{l}\text { AET/PET } \\
\text { (fraction) }\end{array}$ & IM100 & $\begin{array}{c}\mathrm{PET} / \mathrm{P} \\
\text { (fraction) }\end{array}$ \\
\hline 1907-1980 & -124.3 & 405.1 & 140.4 & 60.9 & 0.746 & -22.5 & 1.35 \\
\hline $1981-2011$ & -56.7 & 474.7 & 86.6 & 98.6 & 0.848 & -10.2 & 1.16 \\
\hline
\end{tabular}




\section{Figure Captions}

Fig. 1 Location of Devils Lake Basin, North Dakota (USA). Lake extent is ca. 1999. Large, lake open water surfaces are shown in black; small, wetland open water surfaces are shown in gray. The Sheyenne River Basin is to the immediate south. Source: Sethre et al. (2005)

Fig. 2 Lake volume $\left(\mathrm{km}^{3}\right)$ time series at Devils Lake, North Dakota, through 31 January 2014. The values shown include occasional observations prior to 1901, annual readings through 1930, and monthly values to the present. Source: USGS (2013)

Fig. 3 Histogram of lake volume $\left(\mathrm{km}^{3}\right)$ derived from lake level measurements and lake level-lake volume bathymetry tables. The time series consists of monthly totals from 30 January 1931 through 31 January $2014(\mathrm{~N}=974)$. Source: USGS $(2013,2014)$

Fig. 4 Water year annual precipitation time series $\left(\mathrm{P}_{\mathrm{WY}}, \mathrm{mm}\right)(\mathrm{a})$; Water year mean annual air temperature time series $\left(\mathrm{T}_{\mathrm{WY}},{ }^{\circ} \mathrm{C}\right)(\mathrm{b})$. The period is $1896-2011$ ( $\mathrm{N}=116$ years). Individual years are shown with a plus sign; the nine-term binomial filter of each series is shown as a solid curve; trend lines (dashed) are included with regression statistics.

Fig. 5 Annual precipitation minus annual potential evapotranspiration (PMPE) for Devils Lake, ND (a); Annual potential evaporation minus annual actual evapotranspiration (PET-AET) for Devils Lake, ND (b); Mean annual soil moisture (SM) for Devils Lake, ND (c). All time series are for water years 1895-2011. Individual years are shown with a plus sign; the nineterm binomial filter of each time series is shown as a solid curve; trend lines (dashed) are included with regression statistics.

Fig. 6 Normalized transformed time series plots of lake volume (dashed, 1901-2013), water year precipitation (1896-2013), and mean monthly soil moisture storage (1895-2011). The 
vertical dot-dashed line marks the regime transition occurring in 1980.

Fig. 7 Normalized transformed time series plots of PMPE and PET-AET, 1895-2011. The vertical dashed line marks the regime transition occurring in 1980. 